\title{
CRIMINAL HISTORIES IN PUBLIC HOUSING
}

\author{
LAHNY R. SILVA*
}

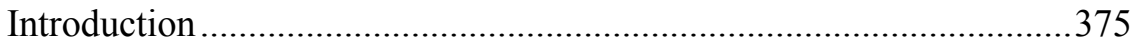

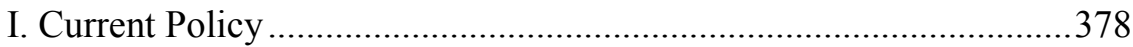

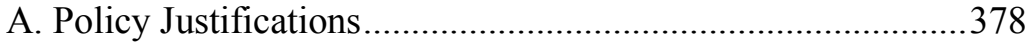

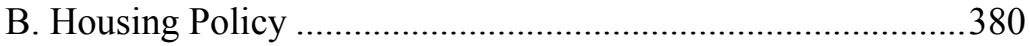

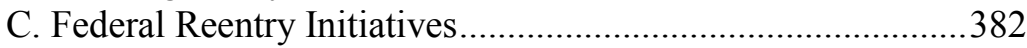

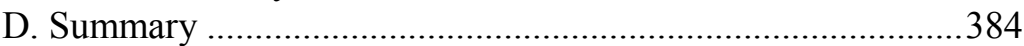

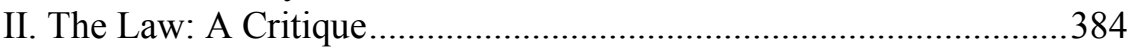

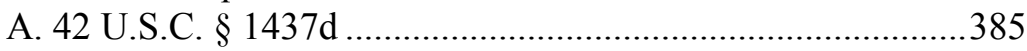

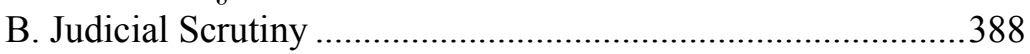

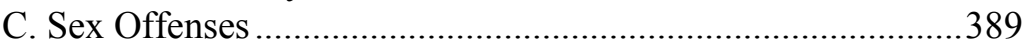

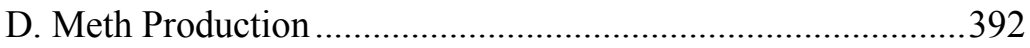

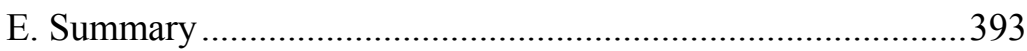

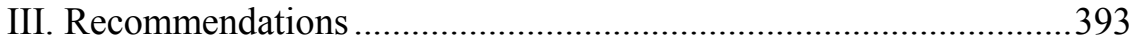

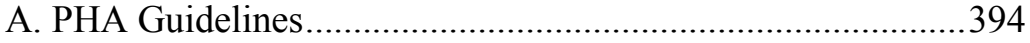

B. Improved Interagency Coordination ........................................395

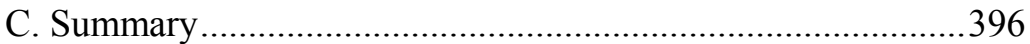

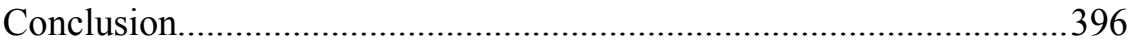

\section{INTRODUCTION}

As America attempts to remedy the harsh sentencing policies enacted during the "War on Drugs" in the 1980s and 1990s, hundreds of thousands of ex-offenders are being released from jails and prisons annually. ${ }^{1}$ Upon release, these individuals will confront legal obstacles in their quest to reenter society. Based solely on the fact of prior criminal conviction, new releasees will inevitably confront statutory "civil"

\footnotetext{
Associate Professor of Law, Indiana University Robert H. McKinney School of Law. I would like to extend gratitude and special thanks to the Wisconsin Law Review and the University of Wisconsin Law School for the opportunity to present my research and assistance in editing this Article. I would also like to thank Professors Florence Roisman, Nicolas Terry, and George Wright at McKinney Law School for their feedback. Finally, I would like to thank Courtney Lee Wilson for convincing me to write this Article and being so supportive.

1. Second Chance Act of 2007, Pub. L. No. 110-199, § 3(b)(1), 122 Stat. 657, 658 (2008) (codified as amended at 42 U.S.C. $\S 17501(b)(1)(2012)$ ). Congress found that approximately 600,000 offenders were being released annually. Id.
} 
penalties severely limiting their most basic opportunities for employment, education, and housing. ${ }^{2}$ Known as "collateral consequences," these penalties relegate ex-offenders to the status of second-class citizens by systematically depriving them of individual rights and privileges. Professor Gabriel "Jack" Chin has classified this socioeconomic phenomenon as the "New Civil Death."3 This Article focuses on one cluster of collateral consequences that deprive those who have paid their debt to society of a basic necessity - affordable housing.

Collateral consequences are sanctions specifically targeted at individuals with criminal convictions. ${ }^{4}$ They operate outside the normal criminal process and are not considered in criminal sentencing determinations. ${ }^{5}$ They are characterized as "civil" in nature and thus exempt from most of the constitutional protections that are triggered by the criminal process. ${ }^{6}$ The basic principle underlying these penalties can be stated simply: individuals who do not play by the rules do not get to play the game. ${ }^{7}$ Thus, those with criminal histories are less deserving of socioeconomic opportunity, as they have demonstrated that they will not play by the rules. ${ }^{8}$

In the past 20 years, reentry scholars and advocates have encouraged the review and reform of a number of collateral consequences. ${ }^{9}$ For example, Christopher Uggen and Jeff Manza's 2000 study demonstrated the way in which felon disenfranchisement could

2. See Jeremy Travis, Invisible Punishment: An Instrument of Social Exclusion, in Invisible Punishment: The Collateral Consequences of Mass IMPRISONMENT 15, 18 (Marc Mauer \& Meda Chesney-Lind eds., 2002).

3. Gabriel J. Chin, The New Civil Death: Rethinking Punishment in the Era of Mass Conviction, U. PA. L. REV. 1789 (2012).

4. See id. at 1790.

5. See Travis, supra note 2, at 16.

6. See id. at 16-17.

7. U.S. Dep't of Hous. \& Urban Dev., "One Strike and You'Re Out" Policy in Public Housing 3 (1996), reprinted in OfFice of Pub. \& Indian Hous., U.S. Dep't of Hous. \& Urban Dev., Notice PIH 96-16 (HA), “One Strike and You're Out” SCREEning AND Eviction Guidelines for Public Housing Authorities (HAs) (1996) [hereinafter HUD, Notice PIH 96-16 (HA)].

8. Id.

9. See, e.g., Travis, supra note 2, at 15-17; Nora V. Demleitner, Preventing Internal Exile: The Need for Restrictions on Collateral Consequences, 11 STAN. L. \& POL'Y REV. 153 (1999); Margaret Colgate Love, Starting Over with a Clean Slate: In Praise of a Forgotten Section of the Model Penal Code, 30 Fordham Urb. L.J. 1705 (2003); Michael Pinard \& Anthony C. Thompson, Offender Reentry and the Collateral Consequences of Criminal Convictions: An Introduction, 30 N.Y.U. REV. L. \& Soc. Change 585 (2006). 
affect election outcomes. ${ }^{10}$ Today, most states reenfranchise upon completion of a criminal sentence. ${ }^{11}$ More recent scholarship that focused on immigration ${ }^{12}$ likely influenced the United States Supreme Court's decision in Padilla v. Kentucky. ${ }^{13}$ Moreover, for the past decade, not-for-profit agencies, as well as governmental bodies such as the Equal Employment Opportunity Commission (EEOC), have worked on implementing fairness standards in both the public and private employment markets. ${ }^{14}$ Housing consequences, while not ignored, must also be critically reexamined and reformed.

This Article adds to the existing reentry scholarship and advocacy by identifying and examining issues in the administration of federal public housing policy and inequities inherent in the current system. More specifically, this Article explores federal public housing policies regarding the use of criminal history information in determining the eligibility of applicants seeking admission to federal public housing programming. This criminal history information includes not only criminal convictions but also arrests and prior drug use. I argue that in light of recent federal reentry initiatives, federal housing law must be substantially reformed.

Currently, federal public housing statutes and regulations are at odds with federal reentry objectives. While recent U.S. Department of Housing and Urban Development (HUD) Secretary Shaun Donovan encouraged a policy of "compassion" in public housing determinations, ${ }^{15}$ little else is being done by way of review and reform. With this in mind, I examine the specific statutory and regulatory authority for the use of criminal records in applicant screening for public housing. This Article discusses the rules for the federal public housing program only. ${ }^{16} \mathrm{I}$

10. Christopher Uggen \& Jeff Manza, Democratic Contraction? Political Consequences of Felon Disenfranchisement in the United States, 67 AM. Soc. REv. 777 (2002).

11. Jean Chung, The Sentencing Project, Felony Disenfranchisement: A PRIMER 2-3 (2014), http://www.sentencingproject.org/doc/publications/fd_Felony\% 20Disenfranchisement\%20Primer.pdf.

12. See, e.g., Jenny Roberts, Ignorance Is Effectively Bliss: Collateral Consequences, Silence, and Misinformation in the Guilty-Plea Process, 95 IowA L. REV. 119 (2009).

13. 559 U.S. 356, 364 n.8 (2010) (citing Roberts, supra note 12, at 124 n.15).

14. See infra notes 163-68 and accompanying text.

15. Letter from Shaun Donovan, Sec'y, U.S. Dep't of Hous. \& Urban Dev., \& Sandra B. Henriquez, Assistant Sec'y, Pub. \& Indian Hous., to Pub. Hous. Auth. Exec. Dir. (June 17, 2011), http://www.bazelon.org/LinkClick.aspx?fileticket=o6OLk7b_6c4\% 3D\&tabid $=537$ [hereinafter Donovan Letter].

16. 42 U.S.C. $\S \S 1437-1437$ e (2012); 24 C.F.R. pts. 5, 900-72 (2014). There are approximately 15 federal housing programs. See generally CATHERINE BISHOP, NAT'L Hous. Law Project, An AfFordable Home on Re-entry: Federally Assisted Housing AND PREVIOUSLY INCARCERATED INDIVIDUALS 165-85 (2008). The 15 programs 
recommend that prior to an admissions disqualification based on criminal history, a more precise eligibility standard be met. I also suggest that interagency collaboration is a critical component in housing new releasees and ex-offenders.

Part I provides an overview of current federal public housing law as well as recent federal reentry initiatives. This serves as the legal basis of the critique. Part II critically examines the specific statutory basis for exclusion based on criminal history in public housing. This Part of the Article reviews the use of criminal history information in eligibility screening as well as identifies problems within the existing admissions framework. Part III recommends two strategies that may provide assistance in providing a practical regulatory framework for those making eligibility determinations in federal public housing programs: PHA guidelines in utilizing criminal history information and more formalized and deliberate interagency collaboration at the local level. Part IV briefly concludes with a recommendation for next steps.

\section{CURRENT POLICY}

\section{A. Policy Justifications}

Current federal public housing policy regarding persons with criminal histories is justified on several grounds. Not surprisingly, safety has always topped the list. ${ }^{17}$ In enacting the Anti-Drug Abuse Act of 1988, and later the National Affordable Housing Act of 1990, congressional findings pointed to criminals "imposing a reign of terror on public and other federally assisted low-income housing tenants." 18 Advocates of exclusionary policies highlight the potential for violence

are the Section 8 Housing Choice Voucher Program, Section 8 Project-Based Vouchers, Public Housing, Federally Assisted Multifamily Rental Housing Programs, Section 221 Below-Market Interest Rate (BMIR) Program, Section 236 Rental Program, Section 202 Program for the Elderly and People with Disabilities, Project-Based Rental Assistance Programs, Section 8 Moderate Rehabilitation Program (RAP), Home Investment Partnership Program, Section 12 Rental Rehabilitation Program, Section 17 Housing Development Program, Low-Income Housing Tax Credit (LIHTC) Program, Section 515 Rural Rental Housing Program, Section 514 and 516 Farm Labor Housing, Shelter Plus Care $(\mathrm{S}+\mathrm{C})$ Program, Supportive Housing Program (SHP), and Housing Opportunities for Persons with AIDS (HOPWA) Program. $I d$.

17. See 42 U.S.C. $§ 11901(1)-(4)$ (2012) (originally enacted as the Anti-Drug Abuse Act of 1988, Pub. L. No. 100-690, § 5122(1)-(4), 102 Stat. 4181, 4301).

18. Cranston-Gonzalez National Affordable Housing Act, Pub. L. No. 101-625, $\S 581(\mathrm{a}), 104$ Stat. 4079, 4245-46 (1990) (codified as amended at 42 U.S.C. $§ 11901(3)$ (2012) (originally enacted as the Anti-Drug Abuse Act of 1988, Pub. L. No. 100-690, $\S 5122(3), 102$ Stat. 4181, 4301)). 
associated with criminal activity. ${ }^{19}$ Thus, any indication of criminal activity on a background check serves as a legitimate basis to exclude individuals from admission to public housing.

There is also the notion that those who have broken the law will not reform; they will continue to disobey authority and present a problem for society. Thus, only the individuals who "play by the rules" ought to be rewarded with federal housing. A HUD Directive issued in 1996 reflects this position:

Because of the extraordinary demand for affordable rental housing, public assisted housing should be awarded to responsible individuals. . . . At a time when the shrinking supply of affordable housing is not keeping pace with the number of Americans who need it, it is reasonable to allocate scarce resources to those who play by the rules. . . . By refusing to evict or screen out the problem tenant, we are unjustly denying responsible and deserving low-income families access to housing and are jeopardizing the community and safety of existing residents who abide by the terms of their lease. ${ }^{20}$

Finally, there is an immense need for public housing in America. The most recent estimates find that there are 45 million people living at or below the federal poverty line, ${ }^{21}$ competing for approximately 4.6 million federally assisted housing units. ${ }^{22}$ Human Rights Watch refers to federal and state public housing policies as a "triage" system whereby eligibility criteria serves to eliminate large groups of people. ${ }^{23}$ Disqualifying individuals with criminal records "has proven to be a politically cost-free way to cut out a large group of people entirely from the pool of those seeking housing assistance."24

However, housing "preferences" favoring applicants who "play by the rules" fail to consider the reentry needs of ex-offenders being

19. See 42 U.S.C. § 11901(3)-(4); see also HUD, NoticE PIH 96-16 (HA), supra note 7.

20. HUD, Notice PIH 96-16 (HA), supra note 7.

21. Carmen Denavas-Walt \& Bernadette D. Proctor, U.S. Dep't of Commerce, U.S. Census Bureau, Income and Poverty in the United States: 2013: Current Population RePORTs, P60-249, at 12 (2014), http://www.census.gov/library/ publications/2014/demo/p60-249.html.

22. Nat'1 Low Income Hous. Coalition, Who Lives in Federally Assisted Housing?: Characteristics of Households Assisted by HUD Programs, Housing SpOtLight, Nov. 2012, at 1, 1 .

23. Corinne Carey, Human Rights Watch, No Second Chance: People with Criminal Records Denied Access to Public Housing 2 (2004), http:/hrw.org/ reports/2004/usa1104/usa1 104.pdf.

24. $I d$. 
released at an exorbitant rate. ${ }^{25}$ Further, while some of these policy justifications may have some merit, they are deaf to the reentry objectives of Congress. Current housing policy remains firm in excluding those that have a criminal history. This is in direct contradiction to the aims of the Second Chance Act of $2007^{26}$ as well as recent HUD initiatives.

\section{B. Housing Policy}

Heavily influenced by the "War on Drugs" agenda of the 1980s and 1990s, current federal housing legislation consists of a hodgepodge of exclusionary policies. Starting with the Anti-Drug Abuse Act of 1988, federal housing law became increasingly restrictive in its admissions criteria while simultaneously expanding public housing authority (PHA) discretion in making admissions determinations. ${ }^{27}$

Focusing on criminality and violence, federal statutes and regulations affect not only the applicant with a criminal history but also his or her household. Four major pieces of federal legislation serve as the foundation of current federal public housing policy: the Anti-Drug Abuse Act of $1988,{ }^{28}$ the Cranston-Gonzalez National Affordable Housing Act of $1990,{ }^{29}$ the Housing Opportunity Program Extension Act of $1996,{ }^{30}$ and the Quality Housing and Work Responsibility Act of $1998 .^{31}$ However, other important provisions also remain buried in various legislative initiatives of the era.

The Anti-Drug Abuse Act of 1988, amending the United States Housing Act of 1937, was the first major piece of legislation through which Congress declared public housing a battleground for America's "War on Drugs." 32 The first major step allocated federal dollars to the

27. See William J. Sabol et al.,U.S. Dep’t of Justice, Bureau of Justice Statistics, Bull. No. NCJ 228417, Prisoners in 2008 (REV. 2010), http://bjs.ojp.usdoj. gov/content/pub/pdf/p08.pdf.

26. See Second Chance Act of 2007: Community Safety Through Recidivism Prevention, Pub. L. No. 110-199, § 101(a)(3), 122 Stat. 657, 661 (2008) (codified as amended at 42 U.S.C. $\S 17501$ (a) (2012)).

27. See Anti-Drug Abuse Act of 1988, Pub. L. No. 100-690, § 5125, 102 Stat. 4181, 4302 (codified as amended at 42 U.S.C. $\$ 11904$ (2012)).

28. Anti-Drug Abuse Act of 1988, Pub. L. No. 100-690, 102 Stat. 4181.

29. Cranston-Gonzalez National Affordable Housing Act, Pub. L. No. 101-625, 104 Stat. 4079 (1990).

30. Housing Opportunity Program Extension Act of 1996, Pub. L. No. 104-120, 110 Stat. 834.

31. Quality Housing and Work Responsibility Act of 1998, Pub. L. No. 105-276, 112 Stat. 2518.

32. Anti-Drug Abuse Act of 1988, Pub. L. No. 100-690, § 5101, 102 Stat. at 4300 (codified as amended at 42 U.S.C. $§ 1437 \mathrm{~d}(l)(2012)$ ). 
HUD Secretary for the purpose of eliminating drug crime from public housing. ${ }^{33}$ By virtue of the Act, the HUD Secretary is authorized to make grants to local PHAs who then establish initiatives to investigate and eliminate drug crime from public housing communities. ${ }^{34}$ While the legislation specifically targets drugs in public housing, enforcement results in the exclusion of those with drug convictions from admission. ${ }^{35}$

The permitted use of criminal records by PHAs in public housing determinations was explicitly established in the Cranston-Gonzalez National Affordable Housing Act of $1990 .^{36}$ The legislation also authorized PHA consideration of the criminal histories of all household members as a factor in eligibility determinations. ${ }^{37}$ Cranston-Gonzalez also created "Preference Rules," whereby Congress listed the preferred households to receive federal housing assistance. ${ }^{38}$ Needless to say, new releasees did not make the list. ${ }^{39}$ Despite the fact that housing ex-offenders has since been identified by the government as a priority, ${ }^{40}$ the legislation remains unchanged.

The Housing Opportunity Program Extension Act of 1996 ordered federal and state law enforcement agencies to comply with PHA criminal records requests. ${ }^{41}$ One of the Act's most prominent features is the modification of the definition of the term "adult," which was changed to include "a person is who is 18 years of age or older, or who has been convicted of a crime as an adult under any Federal, State, or tribal law." Thus, the Housing Program Extension Act permits PHAs to consider the criminal history information of juveniles criminally charged as adults.

The Quality Housing and Work Responsibility Act of 1998 (QHWRA) expanded the discretion of PHAs regarding admissions requirements and criteria. ${ }^{43}$ The Act enables PHAs to condition consideration of admission on household member compliance with

33. Id. $\S 5123,102$ Stat. at 4301 (codified as amended at 42 U.S.C. $§ 11902$ (a) (2012)).

34. Id. $\S \S 5123-24,102$ Stat. at 4301-02 (codified as amended at 42 U.S.C. $\S \S 11902-03(2012))$.

35. 24 C.F.R. $\S \S 960.203(c)(3), 960.204(a)$ (2014).

36. Cranston-Gonzalez National Affordable Housing Act, Pub. L. No. 101-625, $\S 522(\mathrm{~g})(2)(\mathrm{E}), 104$ Stat. 4079, 4212 (1990).

37. $I d$.

38. Id. $\S 501,104$ Stat. at $4180-81$.

39. Id

40. See infra Part I.C.

41. Housing Opportunity Program Extension Act of 1996, Pub. L. No. 104-120, $\S 9$ (b), 110. Stat. 834, 836 (codified at 42 U.S.C. $\S 1437 d(q)(1)(A)(2012)$ ).

42. Id. $\S 9(\mathrm{~b}), 110$ Stat. at $836-37$ (codified at 42 U.S.C. $\S 1437 \mathrm{~d}(\mathrm{q})(8)(\mathrm{A})$ (2012)).

43. Quality Housing and Work Responsibility Act of 1998, Pub. L. No. 105-276, § 502, 112 Stat. 2461, 2520-21. 
criminal background checks. ${ }^{44}$ Additionally, the legislation implements a categorical ban on labeled sex offenders with lifetime registration requirements. ${ }^{45}$ A year later, Congress passed the Independent Agencies Appropriations Act, establishing yet another categorical ban prohibiting admissions of households with a member previously convicted of methamphetamine production on a public housing premise. ${ }^{46}$

In sum, therefore, this cluster of federal statutes authorizes categorical bans and criminal history information as a basis of exclusion from federal public housing. However, such "War on Drugs" legislation is out of step with recent federal reentry initiatives, creating a very real need for review and reform.

\section{Federal Reentry Initiatives}

Over the past 15 years, advocacy and scholarship has brought attention to unnecessarily harsh obstacles to successful reentry. Congress found that over 650,000 people are being released annually back into the community. ${ }^{47}$ The costs of expenditures on corrections swelled from $\$ 9$ billion in 1982 to $\$ 59.6$ billion in 2002 , not including the costs associated with arrest and criminal prosecution. ${ }^{48}$ Congress found a 100 percent increase in children with a parent in prison between 1991 and $1999 .{ }^{49}$ It also found that releasees cite family support as the most critical factor in successful reentry. ${ }^{50}$

The Second Chance Act of 2007, bipartisan legislation enacted to promote federal reentry initiatives, put forth a holistic approach to ex-offender release. ${ }^{51}$ The Act promised to "provid[e] coordinated supervision and comprehensive services for offenders upon release from prison, jail, or a juvenile facility, including housing and mental and physical health care to facilitate re-entry into the community, and which, to the extent applicable, are provided by community-based entities., ${ }^{2}$ The goals underlying these proposed programs include helping

44. Id. $\S 575(\mathrm{~d}), 112$ Stat. at 2637 (codified at 42 U.S.C. $\S 1437 \mathrm{~d}(\mathrm{~s})(2012)$ ).

45. Id. $\S 578(\mathrm{a}), 112$ Stat. at 2641 (codified at 42 U.S.C. $\S 13663(\mathrm{a})$ (2012)).

46. Departments of Veterans Affairs and Housing and Urban Development, and Independent Agencies Appropriations Act, 1999, Pub. L. No. 105-276, § 428, 112 Stat. 2461, 2511 (1998) (codified as amended at 42 U.S.C. $\S 1437 \mathrm{n}(\mathrm{f})(1)(2012)$ ).

47. Second Chance Act of 2007, Pub. L. No. 110-199, § 3(b)(1), 122 Stat. 657, 658 (2008) (codified at 42 U.S.C. $§ 17501(b)(1)(2012)$ ).

48. Id. $\S 3(\mathrm{~b})(4), 122$ Stat. at 659 (codified at 42 U.S.C. $\S 17501(\mathrm{~b})(4)(2012)$ ).

49. Id. $\S 3(\mathrm{~b})(6), 122$ Stat. at 659 (codified at 42 U.S.C. $\S 17501(\mathrm{~b})(6)(2012)$ ).

50. Id. $\S 3(\mathrm{~b})(7), 122$ Stat. at 659 (codified at 42 U.S.C. $\S 17501(\mathrm{~b})(7)(2012)$ ).

51. Second Chance Act of 2007, Pub. L. No. 110-199, § 101(a)(3), 122 Stat. 657, 661 (2008) (codified at 42 U.S.C. § 3797w(b)(3) (2012)).

52. Id. (emphasis added); see also CAREY, supra note 23, at 17-18. 
"offenders to develop safe, healthy, and responsible family relationships and parent-child relationships[,]"53 as well as the inclusion of the entire family unit in the reentry process. ${ }^{54}$ Moreover, the legislation explicitly authorized grant funds to provide housing assistance to adult offenders. ${ }^{55}$

In addition to the Second Chance Act, a cabinet level agency was created to address national reentry concerns. The Reentry Council was established in 2011 by Attorney General Eric Holder with the purpose of assisting ex-offenders upon release. ${ }^{56}$ The Council is interested in identifying, investigating, and resolving obstacles to reentry. ${ }^{57}$ Working in collaboration with HUD, the agency appealed to PHAs, encouraging them "to allow ex-offenders to rejoin their families in the Public Housing . . . programs, when appropriate." ${ }^{, 58}$ In addition, the Council began a dialogue with various federal agencies to discuss best practices and current statutory and regulatory roadblocks to successful reintegration. ${ }^{59}$

A federal partnership among the Department of Justice (DOJ), Department of Labor (DOL), and HUD has resulted in a number of programs that have helped ex-offenders both integrate and positively contribute to their communities. ${ }^{60}$ The Prisoner Reentry Initiative (PRI) is "designed to provide training and job placement services, transitional housing and mentoring to nonviolent ex-offenders.", "On November 8, 2005, the DOL awarded 30 grants to faith-based and community organizations (FBCOs) to develop employment-centered

53. Second Chance Act of 2007, Pub. L. No. 110-199, § 101(a)(4)(A), 122 Stat. at 661 (codified at 42 U.S.C. $\S 3797 \mathrm{w}(\mathrm{b})(4)(\mathrm{A})(2012)$ ).

54. Id. § 101(a)(4)(B), 122 Stat. at 661 (codified at 42 U.S.C. $\S 3797 \mathrm{w}(\mathrm{b})(4)(\mathrm{B})$

55. Id. $\S 111,122$ Stat. at $669-70$ (codified at 42 U.S.C. $\S 3797 \mathrm{w}-2(\mathrm{~b})(4)(\mathrm{A})$ (2012)).

56. Fed. Interagency Reentry Council, Snapshot: Housing, Just. CenteR: CouncIL ST. Gov'TS (June 2013), http://csgjusticecenter.org/wp-content/uploads/2013/ 06/SnapShot.Housing.pdf.

57. $I d$.

58. Donovan Letter, supra note 15; see also Fed. Interagency Reentry Council, supra note 56.

59. Fed. Interagency Reentry Council, supra note 56, at 1-2.

60. Oversight of Federal Assistance for Prisoner Rehabilitation and Reentry in Our States: Hearing Before the Subcomm. on Corrs. \& Rehab. of the Comm. on the Judiciary, 109th Cong. 76 (2006) (written statement of Robert J. Bogart, Director, Ctr. for Faith Based Community Initiatives, U.S. Dep't of Hous. \& Urban Dev.), http://www. gpo.gov/fdsys/pkg/CHRG-109shrg34118/pdf/CHRG-109shrg34118.pdf [hereinafter Bogart Statement]. This partnership and funding has resulted in programs such as Community Oriented Policing Services (COPS), Weed and Seed, and DOL Reintegration Initiative. Senator Coburn Memo Lays Out Reentry Funding, ReEnTRY CourT SOLUTIONS, http://www.reentrycourtsolutions.com/tag/doj-prisoner-reentry-initiative/ (last visited Mar. 25, 2015).

61. Bogart Statement, supra note 60, at 77. 
programming." $" 62$ Transitional housing was also identified as a crucial component to successful reentry. ${ }^{63}$ It was stated that ex-offenders need a place to reside immediately upon release from prison, and HUD can provide the transitional housing needed with relevant supportive services. ${ }^{64}$ PRI funding was needed because HUD lacked the requisite statutory authority to use other HUD funding for reentry or even homelessness prevention. ${ }^{65}$ While Congress recognized housing as an important component to successful reintegration, federal expenditures spent on such housing programming has been sparse. One possible factor contributing to the slow allocation of funding is the contradictory objectives of federal public housing programming and federal reentry initiatives. While HUD rules work to exclude, federal reentry objectives aim to reintegrate.

\section{Summary}

Federal housing legislation targets criminality as a basis for exclusion, while federal reentry aims to emphasize the normative principle of "second chances." Utilizing criminal histories as a disqualifying tool not only undermines reentry aims, it promotes categorical discriminatory practices in determining who in fact deserves a federal benefit. Understanding that the cycle of recidivism is damaging to the country both economically and sociopolitically, the federal government has taken significant steps towards ameliorating some of the pressures associated with reentry. While these efforts are by no means insignificant, an important component must include a comprehensive overhaul of current federal public housing policy.

\section{THE LAW: A CRITIQUE}

The use of criminal history information as the basis for disqualification from federal public housing is patently inconsistent with contemporary federal reentry objectives. Given this inconsistency, it is necessary to investigate and review the legal basis for such practices and amend them where appropriate. Focusing exclusively on the PHA use of criminal history in eligibility determinations, this Part critically examines statutes and regulations authorizing exclusion.

62. Id.
63. Id.
64. Id.
65. Id. at 78.




\section{A. 42 U.S.C. $\S 1437 d$}

As discussed above, Congress authorized PHAs to access and utilize criminal records information for screenings. ${ }^{66}$ PHAs are statutorily authorized to pull applicants' criminal records and use them as an admissions tool once consent from the applicant is obtained. ${ }^{67}$ Federal law gives discretion to local PHAs to decide whether to require a criminal background check as a condition of admission. ${ }^{68}$ The accompanying regulations further permit admissions denials based on "other criminal activity.", While "other criminal activity" is left undefined with little case law on the topic, PHAs are left to fill in the blanks when examining an applicant's criminal record. ${ }^{70}$

Prior to obtaining a criminal history, the adult subject of the criminal records inquiry must consent in writing to the release of such information. ${ }^{71}$ The subject of the accessed criminal record may dispute the accuracy of the record as well as the relevance of the record. ${ }^{72}$ Federal law further requires that PHAs notify applicants of ineligibility determinations. ${ }^{73}$ PHAs are also mandated to inform the applicant of the basis of their decision and also, upon request of the applicant, provide the applicant with the opportunity for an informal hearing. ${ }^{74}$

PHAs may secure criminal records from a variety of law enforcement agencies, including local and state police departments as well as the National Crime Information Center (NCIC). ${ }^{75}$ The NCIC and all other law enforcement agencies are statutorily required to provide

\footnotetext{
66. See supra note 36 and accompanying text.

67. 42 U.S.C. $\S 1437 d(q)(1)(A)(2012) ; 24$ C.F.R. $\S 5.903(a)$ (2014).

68. 42 U.S.C. $\$ 1437 \mathrm{~d}(\mathrm{~s})$. The statute provides:
}

A public housing agency may require, as a condition of providing admission to the public housing program or assisted housing program under the jurisdiction of the public housing agency, that each adult member of the household provide a signed, written authorization for the public housing agency to obtain records ... regarding such member of the household from the National Crime Information Center, police departments, and other law enforcement agencies.

Id.

69. The Nat'l Hous. Law Project, Hud Housing Programs: Tenants' Rights 2/49 (3d ed. 2004) [hereinafter TENANTS' Rights].

70. Id

71. 24 C.F.R. $§ 5.903(b)(2014)$.

72. Id. $\S 5.903(\mathrm{f})$.

73. 42 U.S.C. $\S 1437 d(c)(4)(2012)$.

74. $I d$.

75. Housing Opportunity Program Extension Act of 1996, Pub. L. No. 104-120, $\S 9,110$ Stat. 834, 836 (1996) (codified as amended at 42 U.S.C. $\S 1347 \mathrm{~d}(\mathrm{q})(1)(A)$ (2012)). 
PHAs with the criminal conviction records of adult applicants and residents when PHAs request such information. ${ }^{76}$ With regard to juvenile records, state and local law enforcement agencies are only required to comply with PHA requests if the state authorizes their release. ${ }^{77}$

The accuracy and reliability of criminal history information is dubious at best. A 2003 Bureau of Justice Statistics (BJS) study reported a number of problems with both state and national criminal background databases. ${ }^{78}$ The Federal Bureau of Investigation (FBI) drew a sample from the National Instant Criminal Background Check System (NICS). ${ }^{79}$ This sample contained background information that could not be completed because of "open arrests." ${ }^{" 80}$ BJS reported that "[m]ore than three quarters of the 'open arrests' dated to years prior to $1995^{\prime \prime 11}$ and "[h]alf the 'open arrests' were from 1984 and earlier." 82 BJS stated that "a major 'clean-up' of older records" was necessary. ${ }^{83}$ Reliance on criminal records as the basis for ineligibility may have deleterious consequences for applicants, including homelessness.

In considering admission to public housing, the Code of Federal Regulations pushes PHAs to consider delineated "relevant information," which includes a determination of whether the applicant has a history of criminality. ${ }^{84}$ The regulation provides, "A history of criminal activity involving crimes of physical violence to persons or property and other criminal acts which would adversely affect the health, safety or welfare of other tenants." ${ }^{\prime 5}$ This allows PHAs to consider a broad range of information, including criminal convictions, arrests, and behavior for which an applicant was not arrested, but which satisfies the PHA's understanding of "criminal activity." In order for the PHA to utilize such information in its determination, it must be reasonably related to the individual applicant's attributes and characteristics as opposed to an

76. $\quad 42$ U.S.C. $\S 1437 \mathrm{~d}(\mathrm{q})(1)(\mathrm{A})$.

77. $I d . \S 1437 \mathrm{~d}(\mathrm{q})(1)(\mathrm{C})$.

78. U.S. Dep't of Justice, Bureau of Justice Statistics, National Criminal History Improvement Program (NCHIP): IMPRoving Criminal History RECORDS FOR BACKGROUND CHECKS 1-8 (2003).

79. Id. at 4 .

80. Id.

81. Id.

82. Id.

83. II.

84. 24 C.F.R. $\$ 960.203$ (c)(3) (2014).

85. Id. (emphasis added). 
attribute subscribed to a group or category of individuals to which the applicant may be a member. ${ }^{86}$

Information concerning past indications of criminal activity is aptly phrased "unfavorable information." ${ }^{87}$ However, HUD guidelines suggest that PHAs also "consider the possibility of more favorable future conduct." ${ }^{, 8}$ In addition, PHAs may take into account the gravity and recentness of the criminal activity. ${ }^{89}$ The HUD Public Housing Occupancy Guidebook provides that "[a] criminal record should not automatically exclude an applicant for consideration. The PHA should determine whether the person would be a suitable tenant. ${ }^{, 90}$ As a general rule, an applicant should not be rejected for criminal history that would not affect his or her tenancy. ${ }^{91}$ PHAs are also given the discretion to require an applicant to exclude a household member who the PHA determines has engaged in criminal activity. ${ }^{92}$ Ultimately, however, the decision is left to the PHA. ${ }^{93}$ This often times results in the automatic exclusion of applicants with criminal histories containing specific offenses without an individualized review. ${ }^{94}$

PHAs also determine the length of time of the "exclusion period." 95 They are specifically authorized by federal statute to exclude individuals from public housing longer than required by state and/or federal statute. ${ }^{96}$ The "exclusion" period is the length of time potential applicants must be crime free before they are considered eligible for public housing. ${ }^{97}$ The HUD Public Housing Occupancy Guidebook encourages PHAs to conduct a criminal background check for at minimum the three years prior to possible admission. ${ }^{98}$

In admissions determinations, PHAs are not obligated to satisfy statutorily proscribed criteria nor are they mandated to meet a statutorily

86. Id. $§ 960.203(\mathrm{a})$; see also U.S. DeP’T of Hous. \& URban Dev., PubliC HOUSING OCCUPANCY GUIDEBOOK 48 (2003), http://www.hud.gov/offices/pih/programs/ $\mathrm{ph} /$ rhiip/phguidebooknew.pdf [hereinafter GUIDEBOOK].

87. $§ 960.203(d)$.

88. Id. $\S 960.203(\mathrm{~d})(1)$.

89. Id.

90. U.S. Dep't of Hous. \& Urban Dev., Public Housing Occupancy GUIDEBOOK 4-4 (7465.1 rev. 2), http:/www.hud.gov/offices/adm/hudclips/handbooks/ pihh/74651/74651c4PIHH.pdf.

91. TENANTS' Rights, supra note 69 , at $2 / 46$.

92. $§ 960.203(\mathrm{c})(3)(\mathrm{i})$.

93. Corinne A. Carey, No Second Chance: People With Criminal Records Denied Access to Public Housing, 36 U. ToL. L. REV. 545, 572 (2005).

94. GuIDEBOOK, supra note 86, at 75-76.

95. Id.

96. $§ 960.203(\mathrm{c})(3)(\mathrm{ii})$.

97. Id.

98. GUIDEBOOK, supra note 86, at 97. 
required burden of proof. Both federal statutes and regulations are silent as to a standard of proof in the admissions context. ${ }^{99}$ HUD regulations state that PHAs may deny admission to an applicant if the PHA decides "that any household member is currently engaging in, or has engaged in criminal activity during a reasonable time before the admission decision." 100 Thus, the deck is stacked against the applicant with PHAs making determinations in accordance with locally established rules and customs that are virtually unreviewable.

\section{B. Judicial Scrutiny}

For the past three decades courts have traditionally deferred to PHA eligibility decisions based on criminal history. ${ }^{101}$ Recently, however, there appears to be a shift. For example, in Carbrini-Green Local Advisory Council v. Chicago Housing Authority, ${ }^{102}$ a district court in the Northern District of Illinois struck down a lease provision requiring the eviction of individuals convicted of a felony. ${ }^{103}$ The court determined that the provision constituted a blanket prohibition, thereby expanding the PHA's authority beyond the bounds granted by statute or regulation. ${ }^{104}$ For the court, such an expansion was unnecessary and was not "rationally related to any legitimate housing purpose." provision was struck down. ${ }^{106}$

In Landers v. Chicago Housing Authority, ${ }^{107}$ the Chicago Housing Authority (CHA) rejected the petitioner's application for federal public housing based on an extensive arrest history. ${ }^{108}$ Petitioner Landers was placed on the wait list in 1995, and in 2008 the CHA notified him that he was at the top of the wait list. ${ }^{109} \mathrm{He}$ was subject to a background check for which the CHA utilized a private firm to produce a report. ${ }^{110}$ The

99. TENANTS' RightS, supra note 69 , at 2/49.

100. 24 C.F.R. $\S 5.855$ (a) (2014).

101. See generally Amy Bowser, Comment, One Strike and You're Out-Or Are You? Rucker's Influence On Future Eviction Proceedings for Section 8 and Public Housing, 108 PENN ST. L. ReV. 611 (2003).

102. No. 96 C 6949, 2007 U.S. Dist. LEXIS 6520 (N.D. Ill. Jan. 29, 2007).

103. Id. at $* 2$. The lease provision read, "For termination of the LEASE, the following procedures shall be followed by the LESSOR and the TENANT: . . . The LEASE may be terminated . . . [when] [t] he TENANT or any authorized family member is convicted of a felony." Id. at *3-4 (alterations in original).

104. Id. at *5-6.

105. Id. at *8-9.

106. Id. at $* 2$.

107. 936 N.E.2d 735 (Ill. App. Ct. 2010).

108. Id. at 736 .

109. Id.

110. Id. 
report showed 34 arrests for both felony and misdemeanor offenses. ${ }^{111}$ Landers was denied eligibility based on "a pattern of arrest/conviction." $112 \mathrm{He}$ then requested an informal hearing to dispute the CHA's determination. ${ }^{113}$ At the hearing, Landers produced a criminal history report from the Chicago Police Department. ${ }^{114}$ That report showed four felony arrests, nine misdemeanor arrests, and four ordinance violations. ${ }^{115}$ All of the charges were ultimately dismissed with the exception of one civil ordinance violation. ${ }^{116}$ Landers maintained that the CHA criminal background check was inaccurate because the report contained offenses committed by his twin brother. ${ }^{117} \mathrm{He}$ also testified that a majority of the arrests occurred as a consequence of his homelessness. $^{118}$ Despite this evidence, the CHA denied the application. ${ }^{119}$ Landers appealed to the circuit court, which concluded that although the CHA is permitted to review an applicant's arrest record, the evidence shows that Landers did not pose a threat - almost all arrests resulted in a dismissal and were the consequence of homelessness. ${ }^{120}$ The CHA appealed, ${ }^{121}$ and the appellate court affirmed the trial court finding that the CHA's decision was "clearly erroneous." 122

\section{Sex Offenses}

With the purpose of protecting communities against "dangerous sex offenders," Megan's laws work to exclude thousands from public

\footnotetext{
111. Id.

112. $I d$.

113. $I d$.

114. $I d$.

115. Id. The offenses included drinking on a public way, possession of drug paraphernalia and a controlled substance, criminal trespass, misdemeanor theft and
} assault, and being a fugitive of justice. $I d$. at 737 .

116. Id.

117. $I d$.

118. Id.

119. Id.

120. Id.

121. Id. at 736 .

122. Id. at 742. The court reviewed the CHA's administrative plan rules and regulations. Id. Examining the provision governing rejections based on arrest reports, the court pointed out that the CHA's own policy requires the CHA to place "the applicant's name ... on the wait list until documentation is presented showing the outcome of the case." Id. at 739. For the court, the evidence in the case was "bare bones." Id. at 740 . Recognizing that the CHA is not required to meet any evidentiary standard, the court was displeased that the CHA failed to even meet a preponderance of the evidence standard. Id. at 741 . 
housing. ${ }^{123}$ Most Americans would likely consider this exclusion reasonable when considering the safety and protection of children from sexually violent predators. The NCIC National Sex Offender Registry reports 704,085 registered offenders. ${ }^{124}$ However, not all individuals deemed "sex offenders" are in fact "dangerous sex offenders." Some of the individuals on sex offender registries across the country are young men who engaged in consensual sex with their girlfriends who were a few years younger than themselves. ${ }^{125}$

Federal law categorically bans any individual subject to a state lifetime sex offender registration requirement from federal public housing programs. ${ }^{126}$ The federal statute permits HUD to request a PHA to conduct additional screening. ${ }^{127}$ The statute requires state and local agency compliance. ${ }^{128}$ Sex offender screening involves an inquiry into the state in which the housing is located as well as other states where the household previously resided. ${ }^{129}$ Beyond that, PHAs are required to develop their own screening procedures. ${ }^{130}$ The statute also requires PHAs to provide "the tenant or applicant with a copy of the registration information and an opportunity to dispute the accuracy and relevance of that information." $" 131$

There are few published opinions involving potential tenants challenging a PHA's exclusionary policy. One such challenge was brought by Pine Tree Legal Services in Maine. ${ }^{132}$ In Oullette v. Housing Authority of the City of Old Town, ${ }^{133}$ the City of Old Town's PHA implemented a policy that indefinitely excluded individuals convicted of violent criminal activity in the past. ${ }^{134}$ The plaintiff had been convicted

123. Maureen S. Hopbell, Balancing the Protection of Children Against the Protection of Constitutional Rights: The Past, Present and Future of Megan's Law, 42 DUQ. L. REV. 331, 342 (2004).

124. U.S. Dep't of Justice, Bureau of Justice Statistics, Survey of State CRIMINAL History INFORMATION SYSTEMS, 2012, at 5 (2014).

125. Legislatively Mandated Categories of Exclusion from Public Housing, HuM. RTS. WATCH, http://www.hrw.org/reports/2004/usa1104/8.htm (last visited Feb. 5, 2015).

126. 42 U.S.C. $§ 13663(a)$ (2012) ("Notwithstanding any other provision of law, an owner of federally assisted housing shall prohibit admission to such housing for any household that includes any individual who is subject to a lifetime registration requirement under a State sex offender registration program.”).

127. Id. $\S 13663(\mathrm{~b})(1)$.

128. Id. $\S 13663(\mathrm{~b})(2)$.

129. 24 C.F.R. $\S \S 5.905(a)(1), 5.856$ (2014).

130. Id. $\S 5.856$.

131. 42 U.S.C. $\S 13663(d)$.

132. Ouellette v. Hous. Auth. of the City of Old Town, No. AP-03-17, 2004 Me. Super. LEXIS 60 , at $* 1$ (Mar. 12, 2004).

133. Id.

134. Id. at *2-3. 
of a sex offense 15 years before applying for public housing. ${ }^{135}$ Moreover, his conviction occurred before the implementation of sex offender lifetime registration requirements. ${ }^{136}$ Because he was not required to register, the federal ban on sex offender admissions did not apply. ${ }^{137}$ The Maine court concluded that the PHA failed to consider the time that had passed between his conviction and his application. ${ }^{138}$ In response to the PHA argument that admissions to public housing are entirely discretionary, the court reasoned that the clear intent of HUD regulations "mandate a consideration of whether a reasonable time had passed since the conviction .... In the absence of such a consideration and finding, the [PHA] has circumvented this necessary analysis." 139

Zimbleman v. Southern Nevada Housing Authority ${ }^{140}$ is an example of how some courts interpret the federal ban as mandating exclusion of previously admitted sex offenders subject to a lifetime registration requirement. ${ }^{141}$ Petitioner Zimbleman, a convicted sex offender subject to lifetime registration, applied to federally assisted housing. ${ }^{142} \mathrm{He}$ disclosed his sex offender status on his application and was admitted. ${ }^{143}$ The housing authority subsequently evicted Zimbleman because of his sex offender status. ${ }^{144}$ He sued the PHA pursuant to 42 U.S.C. $\S 1983$ and requested a preliminary injunction. ${ }^{145}$ The district court refused to issue the order. ${ }^{146}$ On appeal, the Ninth Circuit affirmed the district court. ${ }^{147}$ By contrast, in Miller v. McCormick, ${ }^{148}$ the District of Maine determined that the lifetime registration requirement was not a basis for evicting a tenant previously granted federal housing assistance. ${ }^{149}$ The

135. See id. at *1.

136. Compare id. at *1 n.1 (stating that the Ouellette's conviction for aggravated felonious sexual assault was entered in New Hampshire on June 15, 1990), with 42 U.S.C. $§ 14701$ (requiring that each state implement a sex offender lifetime registration program "not more than 3 years from Sept. 13, 1994").

137. See id.

138. Id. at $* 4-5$.

139. $I d$.

140. 583 F. App'x 704 (9th Cir. 2014).

141. See id. at 705 .

142. Id. at 704-05.

143. Id. at 705 .

144. Id.

145. Id.

146. Id.

147. $I d$.

148. 605 F. Supp. 2d 296 (D. Me. 2009); see also Perkins-Bey v. Hous. Auth. of St. Louis Cnty., No. 4:11CV310 JCH, 2011 U.S. Dist. LEXIS 25438 (E.D. Mo. Mar. 14, 2011); Bonseiro v. N.Y.C. Dept. of Hous., Preserv. \& Dev., 950 N.Y.S.2d 490 (N.Y. Sup. Ct. 2012).

149. Miller, 605 F. Supp. 2d at 312. 
court recognized that the PHA had statutory power (and indeed the obligation) to deny admission to Miller. ${ }^{150}$ However, the court concluded that the exclusionary power only applied to admission and did not permit termination. $^{151}$

Ultimately, most "sex offenders" will return to the community, and housing this demographic is critical. They are not only ex-offenders in desperate need of housing; this group is often ignored in the national conversation concerning reentry. Without any real prospect of stable housing, many sex offenders have taken to living in tents, shelters, and literally on the streets. ${ }^{152}$

\section{Meth Production}

Federal law also categorically bans the admission of households with a member previously convicted of manufacturing methamphetamine on public housing premises. ${ }^{153}$ The inherent dangerousness and toxicity involved in the process of production are a grave public safety concern. Cosponsored by Senators Kit Bond and John Ashcroft, the exclusion was meant to send a message: "If you want to turn your taxpayer-subsidized residence into a meth lab, the only public housing you will be eligible for in the future is the penitentiary." 154 With little discussion, the bill was passed. ${ }^{155}$ While applicable to the federal public housing program, this prohibition does not apply to all federal housing programs.

150. Id. at 309 .

151. Id.

152. Joseph Goldstein, Housing Restrictions Keep Sex Offenders in Prison Beyond Release Dates, N.Y. TIMES, Aug. 21, 2014, http://www.nytimes.com/2014/08/ 22/nyregion/with-new-limits-on-where-they-can-go-sex-offenders-are-held-after-servingsentences.html; Juliana Keeping, Oklahoma City Says Sex Offenders Can't Live in Tents at Trailer Park, NewsOK (July 30, 2012), http://newsok.com/oklahoma-city-says-sexoffenders-cant-live-in-tents-at-trailer-park/article/3696607; Isaiah Thompson, Homeless Sex Offenders Face Eviction, MiAMI NEW TIMES (Feb. 7, 2008), http://www. miaminewtimes.com/2008-02-07/news/homeless-sex-offenders-face-eviction/full; Chuck Williams, Where Do Homeless Sex Offenders Go in Columbus?, LEDGER-ENQUIRER (Nov. 15, 2014), http://www.ledger-enquirer.com/2014/11/15/3416279/where-dohomeless-sex-offenders.html; John Zarrella \& Patrick Oppmann, Florida Housing Sex Offenders Under Bridge, CNN (Apr. 6, 2007, 1:16 AM), http://www.cnn.com/2007/ LAW/04/05/bridge.sex.offenders/.

153. 42 U.S.C. $\S 1437 \mathrm{n}(\mathrm{f})(2012)$.

154. CAREY, supra note 23, at 70 (quoting 144 CONG. REC. S8269, S8366 (daily ed. July 16, 1998) (statement of Sen. Ashcroft)).

155. Id. 


\section{E. Summary}

Whether dealing with the general offender as a class or specific subsets, such as sex offenders, some restrictions from public housing are likely justified. However, current federal statutes and regulations demonstrate that PHAs are authorized to exclude first and ask questions later. ${ }^{156}$ Absent statutorily mandated exclusions, it is wholly within the discretion of PHAs to have a strict exclusionary policy within the context of admission to federal public housing. ${ }^{157}$ Recent federal reentry initiatives, however, require a reexamination of federal public housing policies. More critically, PHAs must be educated about the federal initiatives to begin the process of better assessment of applications to federal public housing.

\section{RECOMMENDATIONS}

The American Bar Association (ABA), ${ }^{158}$ the EEOC, and Human Rights Watch are just a few groups at the forefront of the movement to remove the legal and institutional barriers to successful reintegration. With approximately 600,000 offenders being released back into the community annually for years to come, ${ }^{159}$ think tanks, national advocacy organizations, scholars, and professional associations are focusing their attention on removing legal obstacles to reentry. Moreover, the recent creation of the Reentry Council coupled with HUD's recent reintegration initiative adds to the discussion and, more importantly, implementation of reentry goals.

The dialogue regarding collateral consequences generally, and employment specifically, has resulted in administrative, regulatory, and sociopolitical reform. Issues concerning housing are just starting to percolate. The conversation is beginning in a number of forums including Human Rights Watch, the Reentry Council, ${ }^{160}$ and the Legal Action Center. ${ }^{161}$ Moreover, HUD currently is working with the DOJ to examine ways in which HUD can provide resources to assist in housing ex-offenders. ${ }^{162}$ Nevertheless, it remains essential that current federal

156. Carey, supra note 93, at 572.

157. Id.

158. See Am. Bar Ass'n, Criminal Justice Section, Survey on Reentry.

159. 42 U.S.C. $\S 17501$ (b)(1) (2012).

160. Fed. Interagency Reentry Council, supra note 56.

161. Legal Action Center, Public Housing Authority Admission Policies for People with CRiminal Records and AdDiction Histories, http://lac.org/wpcontent/uploads/2014/07/Housing_Policies_for_People_with_Criminal_Records_and_Ad diction_Histories_LAC_one-pager_2_.pdf.

162. Fed. Interagency Reentry Council, supra note 56. 
housing statutes and regulations be reviewed and reformed where appropriate to reflect a consistent national reentry strategy.

\section{A. PHA Guidelines}

One possibility is the establishment of standards to better assist PHAs making admissions determinations. In 2012, the EEOC issued an official guidance document regarding the use of arrest and conviction records in employment determinations. ${ }^{163}$ Human Rights Watch found the guidance "instructive by way of comparison with PHA practice."164

The guidelines recommend that employers subject to Title VII develop a "narrowly tailored" written policy regarding screening procedures for applicants with criminal records. ${ }^{165}$ This policy should understand the job requirements as well as "the actual circumstances under which the jobs are performed."166 The policy should further identify those specific offenses that may conflict with stated job requirements. ${ }^{167}$ Additionally, the EEOC suggests that employers conduct an individualized assessment of applicants with criminal records considering the duration of an exclusion for such criminal conduct. ${ }^{168}$ Comparing PHA practices to the EEOC framework provides guidance that is transferable to the public housing context. While federal housing statutes and regulations contemplate the use of criminal records as a screening tool, they are rarely "narrowly tailored" and fail to mandate individualized assessments. Moreover, PHAs are not required to establish policies specific to criminal records screening. A directive from Congress mandating HUD to develop a formal written policy narrowly tailored to meet specifically delineated housing objectives as well as reentry and family unification goals will require HUD and local PHAs to think through issues associated with current practices. At a minimum, this approach necessitates a balance between public housing goals,

163. U.S. EQUAL EMPLOYMENT OPPORTUNity COMM'N, EEOC ENFORCEMENT Guidance No. 915.002: Consideration of ARREST AND CONVICTION ReCORdS in EMPloyment Decisions Under Title VII of the Civil Rights ACt OF 1964 , available at http://www.eeoc.gov/laws/guidance/upload/arrest_conviction.pdf [hereinafter EEOC ENFORCEMENT GUIDANCE].

164. CAREY, supra note 23, at 48.

165. EEOC ENFORCEMENT GUIDANCE, supra note 163, at 14, 25.

166. Id. at 25 .

167. Id.

168. $I d$. 
identifiable risks associated with an applicant's criminal history, and the applicant's housing need. ${ }^{169}$

\section{B. Improved Interagency Coordination}

Improved interagency coordination is a necessity. While the creation of the Reentry Council is a step forward, more formal coordination and communication must be established at all levels of government, from the Reentry Council and HUD to local PHAs and county correctional facilities. Such collaboration will likely produce housing opportunities for new releasees and other qualified ex-offenders.

A New York City study reported that over 30 percent of single adults in homeless shelters are new releasees. ${ }^{170}$ The study also reported that many of these individuals become entrenched in the cycle of recidivism and incarceration. ${ }^{171}$ With the federal government's recent interest in reentry, the stage has been set for a federal reentry initiative that includes public housing. Interagency collaboration provides reentry initiatives with expansive federal backing and multiplies the number of possibilities likely to result in savings of federal dollars as well as a decline in recidivism.

Different cities across the country have invested taxpayer dollars in supportive services to new releasees with positive outcomes. Saint Andrew's Court in Chicago provides such an example; a collaboration among the St. Leonard's Ministries in Chicago, Lakefront Single Room Occupancy (SRO), the Illinois Department of Corrections, the City of Chicago, and the Illinois Housing Development Authority resulted in the investment of a housing facility meant to provide long-term supportive housing for men with criminal histories or a record of homelessness. ${ }^{172}$ Opened in 1998, the facility now houses 42 men. ${ }^{173}$ In 2008, clients who completed the program at St. Andrew's Court only had a 26 percent recidivism rate. ${ }^{174}$

169. Human Rights Watch suggests that information concerning criminal history be evaluated in light of "whether there is a public safety reason for excluding those with criminal records." CAREY, supra note 23 , at 48.

170. Katherine Cortes \& Shawn Rogers, Bureau of Justice Assistance, Just. Center: The Council of St. Gov'ts, Reentry Housing Options: The POLICYMAKERS' GuIDE, at vii (2010), https://www.bja.gov/Publications/CSG_Reentry_ Housing.pdf.

171. Id

172. Id.

173. Id.

174. Id. at 15 . 


\section{Summary}

While many federal housing statutes and regulations must be re-assessed, issues in the context of PHA administration are in desperate need of review. Such an examination ought to consider federal reentry aims as well as the possibility of amending current statutory and regulatory language to reflect "Second Chance" goals. Particular attention ought to be paid to the amount of PHA discretion in admissions as well as the lack of statutory or regulatory guidance regarding the use of criminal history information in PHA determinations. In considering the implementation of a framework that cabins some PHA discretion, the EEOC Title VII Guidance directive ought to be utilized as a model. The policy strikes the appropriate balance between an applicant's criminal history and the reasonable concerns of a given agency. Employing such a framework in PHA admissions procedure will likely stop the further exercise of a "deny first" approach while simultaneously advancing federal reentry goals of reintegration.

Interagency collaboration will provide a broader net to catch those most in need of housing and a second chance. Constant and consistent communication between housing agencies and reentry organizations will likely facilitate funding opportunities for housing ex-offenders in hopes of replicating the recidivism rate of St. Andrews Court in Chicago. These two recommendations may prove most helpful to those on the ground, including, legislators, PHAs, and advocacy organizations.

\section{CONCLUSION}

Current federal housing policy is that those with criminal histories are unwelcome applicants. With federal reentry initiatives gaining significant momentum in the last decade, current public housing policy must be seriously reevaluated and reformed. At the very least, there must be a more formal collaboration between HUD and the Reentry Council aimed at reintegrating ex-offenders in meaningful ways. This will allow for an open dialogue between the two agencies as well as a check on HUD rules and PHA practices, thereby ensuring consistency in federal policies.

This Article addresses but one subsection of a federal statute and the corresponding federal regulations governing the administration of federal public housing. One possible step in addressing the use of criminal history information in federal housing determinations is the review of other federally assisted housing program rules. There are over a dozen federal housing programs that must also undergo close reexamination, including Section 8, Shelter Plus Care, and Supportive Housing. A deliberate effort must be made to adjust current federal housing rules to 
reflect recent reentry aims. Policies governing the use of criminal history information in other programs should also adequately balance the applicant's criminal history and legitimate housing concerns. In addition, litigation must also continue to challenge both the law and local PHA practices and policies. Recent cases, such as Cabrini Green, are small victories that add up in the struggle for a second chance. 